\title{
Expression of tight junction and drug efflux transporter proteins in an in vitro model of human blood-brain barrier
}

\author{
${ }^{1}$ Department of Neurological, Neurosurgical and Behavioral Sciences, University of Siena, Siena, Italy \\ 2 Siena Biotech S.p.A., Siena, Italy \\ ${ }^{3}$ Neurosurgery Unit, Medical School Hospital, Siena, Italy
}

Chiara Cioni ${ }^{1}$, Elisa Turlizzi ${ }^{2}$, Ugo Zanelli $^{2}$, Giuseppe Oliveri ${ }^{3}$ and Pasquale Annunziata ${ }^{1}$ *

\section{Edited by:}

Silke Vogelgesang, University of

Greifswald, Germany

Reviewed by:

Samir Kumar-Singh, Antwerp

University, Belgium

Laszlo Siklos, Biological Research

Center, Hungary

Celine Adessi, Roche

Pharmaceuticals, Switzerland

*Correspondence:

Pasquale Annunziata, Dipartimento di Scienze Neurologiche,

Neurochirurgiche e del

Comportamento, Centro

Interdipartimentale per lo Studio e la

Terapia della Sclerosi multipla e delle

Malattie Neuroimmunologiche,

Università di Siena, Viale Bracci, 2,

53100 Siena, Italy.

e-mail:annunziata@unisi.it
Interendothelial cell tight junctions (TJs) proteins contribute to maintain the structural and functional integrity of the blood-brain barrier (BBB) and several efflux transporters regulate transport of compounds across BBB. A unique double compartment-model of the BBB, consisting of cerebral endothelial cells isolated from cryopreserved human glial tumors, alone and in the presence of human astroglial cells derived from the same tissue preparation was established. Endothelial cell viability and transendothelial electrical resistance (TEER) were measured in this model and three representative TJ proteins - occludin (OCLN), zonula occludens-1 (ZO-1) and claudin-5 (CLN-5) - as well as several drug efflux transporters - P-glycoprotein (P-gp), multidrug resistance protein-1 and 2 (MRP-1 and MRP-2), organic anion-transporting polypeptide-1 and 3 (oatp1 and oatp3) were analyzed at both the protein and gene transcript level. Functional activity of P-gp and MRP-1 was also assessed. Endothelial cell viability as well as TEER significantly increased in the presence of glial cells. A significant increase of expression of OCLN, ZO-1, and CLN-5 proteins as well as of several drug transporter proteins except oatp3 and MRP-1, was also found in the presence of glial cells. All the gene transcripts protein analyzed were found to be significantly increased in the presence of glial cells. A suitable functional activity of P-gp and MRP-1 was also found. These results demonstrate that this brain endothelium culture system mimics a physiologically relevant situation and may therefore provide a new tool for studying the effects of biological fluids such as serum and cerebrospinal fluid from patients with neurological disorders underlying a BBB alteration in disease pathogenesis.

Keywords: blood-brain barrier, brain endothelium, glia, tight junctions, drug transporters, cell culture

\section{INTRODUCTION}

The blood-brain barrier (BBB) is a specialized system, consisting of brain microvascular endothelial cells and astroglial cell endfeet, that protects the brain from potentially toxic substances and regulates the passage of circulating molecules on the basis of their size and physical-chemical characteristics, regulated by selective transporters thus contributing to the maintenance of brain parenchyma homeostasis. The structural and functional integrity of the BBB is maintained by interendothelial cell tight junctions (TJs), which are characterized by several integral proteins including claudins and occludin, linked to the actin cytoskeleton by other scaffolding proteins such as zonula occludens (ZO; Ballabh et al., 2004). Transport across the $\mathrm{BBB}$ also depends on several efflux transporters expressed by brain endothelial cells, including P-glycoprotein (P-gp; Cordon-Cardo et al., 1989), organic anion-transporting polypeptide (oatp; Gao et al., 1999) and multidrug resistance proteins (MRPs; Culot et al., 2008). These efflux proteins actively pump compounds out of the endothelial cells and back into the blood (De Lange, 2004), reducing the exposure of the central nervous system (CNS) to delivered drugs. These barrier properties are mostly induced and maintained by the close association between astrocytic foot processes and the brain capillary endothelial cells
(Bradbury, 1985, 1993; Goldstein and Betz, 1986). Several in vitro models have been developed over the last two decades to study the physiology, pharmacology and pathophysiology of the BBB. Most of these models were based on the use of primary endothelial cell cultures prepared with brain capillaries, umbilical veins and aorta isolated from human, porcine, bovine, rodent, and murine species (Biegel et al., 1995; Teifel and Friedl, 1996; Cecchelli et al., 1999; Abbott, 2000). Due to the known role of astrocytes in inducing and maintaining $\mathrm{BBB}$ properties and integrity in the brain endothelium (Arthur et al., 1987; Janzer and Raff, 1987), endothelial cells have been co-cultured with primary rat astrocytes as well as rat or human glial tumor cell lines, cell-conditioned media or pericytes (Dehouk et al., 1990; Meyer et al., 1990, 1991; Rubin et al., 1991; Perrière et al., 2007). However, there are also a few in vitro BBB models based on commercially available primary human brain endothelium cultures or on immortalized human cell lines in the presence or absence of human astroglial cells (Megard et al., 2002; Weksler et al., 2005). BBB alterations have been found to play a role in the pathogenesis of several human neurological diseases, including multiple sclerosis (Kermode et al., 1990) and HIV-related neurological disorders (Smith et al., 1990), while changes in the endothelial cell basement membrane have been 
demonstrated in autopsy brains from patients with Alzheimer's disease (Kalback et al., 2004). An in vitro BBB model capable of reproducing most of the characteristics of the adult human $\mathrm{BBB}$ and overcoming possible species differences mainly related to endothelial surface receptors could therefore represent a valid tool for the study of BBB alterations in CNS pathologies. To address this issue, we established a unique double compartment-model of the $\mathrm{BBB}$, consisting of cerebral endothelial cells isolated from cryopreserved human primary brain tumors, alone and in the presence of human astroglial cells derived from the same tissue preparation. In this model, we measured endothelial cell viability and transendothelial electrical resistance (TEER) and analyzed three representative TJ proteins - occludin (OCLN), zonula occludens1 (ZO-1), and claudin-5 (CLN-5) as well as several drug efflux transporters (P-gp, MRP-1, MRP-2, oatp1, and oatp3) at both the protein and gene transcript level. Part of this study was presented at the 19th Meeting of the European Neurological Society and published elsewhere as abstract (Cioni et al., 2009).

\section{MATERIALS AND METHODS}

\section{HUMAN BRAIN ENDOTHELIAL CELL CULTURES}

Human cerebral endothelial cells were isolated from glioma specimens obtained during neurosurgical operations, and preserved in liquid nitrogen in cryopreservation medium (DMEM-20\% FCS8\% DMSO) until use, as previously described (Brunet et al., 2003). All patients gave their informed consent according to the rules approved by the Ethics Committee of the University of Siena. For this work, specimens from three different tumors were used. A list of the tumor characteristics is shown in Table 1.

Prior to cryopreservation, the meninges were removed and the tissue was rinsed three times in DMEM to remove blood. After thawing in a water bath at $37^{\circ} \mathrm{C}$ for less than $1 \mathrm{~min}$, brain tissue was minced into small pieces, rinsed several times in DMEM and then homogenized in Ringer's solution: $10 \mathrm{mM}$ Hepes $\mathrm{pH}$ 7.4. The microvessel fraction was obtained using a previously described technique (Mrsulja et al., 1976) and microvessel samples were pooled in Hank's solution at pH 7.4 and then centrifuged. The cells were dissociated with $0.1 \%$ trypsin in Hank's solution $\mathrm{pH}$ 7.4 for $15 \mathrm{~min}$ at $37^{\circ} \mathrm{C}$ and digested for $2 \mathrm{~h}$ at $37^{\circ} \mathrm{C}$ with collagenase/dispase $(2 \mathrm{mg} / \mathrm{ml})$ and DNase $(10 \mu \mathrm{g} / \mathrm{ml})$ in DMEM. After blocking digestion by feeding medium, the cells were resuspended in $5 \mathrm{ml}$ of DMEM-20\% FCS, placed in a Petri dish and incubated in an atmosphere of air with $5 \% \mathrm{CO}_{2}$ at $37^{\circ} \mathrm{C}$. After 2 days, the feed solution was removed and centrifuged, then the pellet was resuspended in $5 \mathrm{ml}$ of feed medium and seeded again in a Petri

Table 1 | Clinical and histological characteristics of the glial tumors used in the study.

\begin{tabular}{llll}
\hline $\begin{array}{l}\text { Sex and } \\
\text { age (years) }\end{array}$ & Tumor type & Histological grade & Localization \\
\hline M 68 & Astrocytoma & Grade II & Right frontal lobe \\
F 59 & Glioblastoma & Grade IV & Left temporal lobe \\
F 61 & Astrocytoma & Grade IV & Right frontal lobe \\
\hline
\end{tabular}

$M$, male subject; $F$, female subject. dish. The cells grew slowly as sheets and/or networks of elongated cells, covering the entire surface of the dish in 3-4 weeks. In all the cultures, 98-99\% of the cells were positive for Factor VIII, a reliable marker of endothelial cells, which was detected as previously described (Annunziata et al., 1995). No cells positive for glial fibrillary acidic protein (GFAP), a reliable marker of astroglial cells, were detected as below described, indicating the absence of residual glioma cells. When they reached confluence, the cells were trypsinized in $0.1 \%$ trypsin in Hank's solution at $\mathrm{pH}$ 7.4 for $15 \mathrm{~min}$ at $37^{\circ} \mathrm{C}$, counted (for each $35 \mathrm{~mm}$ Petri dish, nearly $2 \times 10^{6}$ cells were yielded) and seeded in 96-well microplates (Nunc, Denmark) or in multi-well inserts (Nunc) at a density of $2 \times 10^{4}$ cells/well or insert, in a feed medium consisting of $20 \%$ heat-inactivated FCS, $5 \mathrm{mg} / \mathrm{ml}$ peptone, $25 \%$ glucose, $1 \%$ vitamins, $1 \%$ amino acids, $1 \%$ antibiotic-antimycotic solution, and $2 \mathrm{mM}$ L-Glutamine in DMEM (all from Sigma, St. Louis, USA). The culture viability was tested at 1,7 , and 14 days in vitro (DIV) using a MTT assay as previously described (Annunziata et al., 1998), and TEER was tested at the same times. The highest viability and TEER values were found at 7 DIV and remained stable until 14 DIV (data not shown); 7 DIV was therefore chosen as the cell stage time-point for all assays. A representative confluent monolayer of human brain endothelial cell culture is shown in Figure 1.

\section{TRANSENDOTHELIAL ELECTRICAL RESISTANCE MEASUREMENT}

Primary human brain endothelial cells were seeded on multi-well inserts $(0.2 \mu \mathrm{m}$ pore size) for 96-well microplates (Nunc). Resistance was measured using an assembly containing current-passing and voltage-measuring electrodes (World Precision Instruments Inc., Sarasota, FL, USA) according to the manufacturer's instructions. The final resistance $\left(\Omega \mathrm{cm}^{2}\right)$ was calculated as unit area resistance obtained by multiplying the meter readings by the effective surface area of the filter membrane. The value of blank filters was subtracted from that of filters with cells.

\section{HUMAN ASTROGLIAL CULTURES}

The astrocyte fraction was obtained from the same tumor pool as the cerebral endothelial cells. The astrocytes were isolated from the middle fraction, obtained by density gradient centrifugation, according to the technique used for microvessel isolation (Mrsulja et al., 1976). The fraction was rinsed three times with

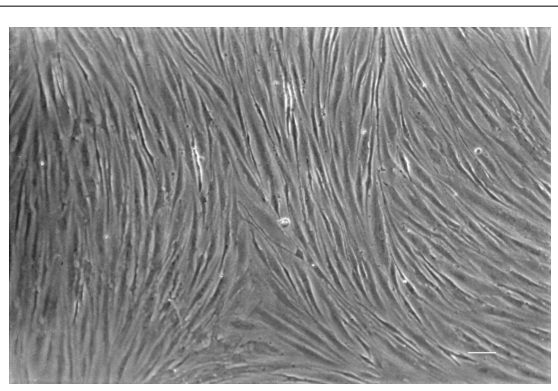

FIGURE 1 | Phase contrast image of a representative confluent monolayer of human brain endothelial culture at 30 days in vitro (DIV) prepared from glioblastoma listed in Table 1. Scale bar $=200 \mu \mathrm{m}$. 
complete feed medium consisting of $20 \%$ heat-inactivated FCS, $5 \mathrm{mg} / \mathrm{ml}$ peptone, $25 \%$ glucose, $1 \%$ vitamins, $1 \%$ amino acids, $1 \%$ antibiotic-antimycotic solution, and $2 \mathrm{mM} \mathrm{L-Glutamine} \mathrm{in}$ DMEM. The pellet was then resuspended in the same medium in a Petri dish and incubated in an atmosphere of air with 5\% $\mathrm{CO}_{2}$ at $37^{\circ} \mathrm{C}$. The cells grew quickly, covering the entire surface of the dish in 1 week. When they reached confluence the cells were trypsinized with $0.1 \%$ trypsin in Hank's solution at pH 7.4 (15 min at $37^{\circ} \mathrm{C}$ ), then counted and seeded in 96-well microplates (Nunc) at a density of $2 \times 10^{4}$ cells/well in the same feed medium as the cerebral endothelial cultures. In all the cultures, $99 \%$ of the cells were found to be positive for GFAP using an immunofluorescence assay with anti-GFAP monoclonal antibody (Exbio, Prague) and FITC-conjugated goat anti-mouse IgG (Calbiochem). No Factor VIII-positive cells were detected, indicating absence of endothelial cells. The cell viability was tested at 7 DIV with a previously described MTT assay (Annunziata et al., 1998).

\section{CO-CULTURES OF HUMAN BRAIN ENDOTHELIAL CELLS AND GLIOMA CELLS}

For co-cultures, $2 \times 10^{4}$ brain endothelial cells in the complete DMEM medium reported above were seeded in tissue culture inserts (Nunc, Denmark) for 96-well microplates (Nunc) and $2 \times 10^{4}$ glial cells were seeded in the corresponding bottom well in the same medium. In some control experiments, endothelial cells were cultured alone in 96-well microplates.

\section{CELLULAR ELISA OF TIGHT JUNCTION AND DRUG EFFLUX PROTEINS}

After washing with 1\% BSA in PBS at pH 7.4 and fixing for $20 \mathrm{~min}$ at room temperature with $4 \%$ paraformaldehyde in $\mathrm{PBS}$ at $\mathrm{pH} 7.4$, the endothelial cell cultures were washed again and overlaid with $3 \% \mathrm{H}_{2} \mathrm{O}_{2}$ in methanol for 30 min to block endogenous peroxidase, followed by $20 \%$ normal mouse, goat, or rabbit sera (Dako) to block unspecific immunoglobulin binding. The cell cultures were incubated for $2 \mathrm{~h}$ at room temperature with either polyclonal goat anti-ZO- 1 antibody $(4 \mu \mathrm{g} / \mathrm{ml}$, Santa Cruz), peroxidase conjugated monoclonal mouse anti-occludin antibody $(1 \mu \mathrm{g} / \mathrm{ml}$,
Zymed), monoclonal mouse anti-P-gp ( $2 \mu \mathrm{g} / \mathrm{ml}$, Alexis $)$, monoclonal mouse anti-MRP-1 $(10 \mu \mathrm{g} / \mathrm{ml})$, or anti-MRP-2 $(10 \mu \mathrm{g} / \mathrm{ml}$; Alexis), polyclonal rabbit anti-oatp1 or oatp3 $(1 \mu \mathrm{g} / \mathrm{ml}$, Chemicon). As controls, after washing cell cultures were also incubated with the corresponding antibody isotypes (all from Ancell) at the same concentration and for the same time as the primary antibody. After washing, affinity purified peroxidase conjugated anti-goat, mouse or rabbit IgG (all from Calbiochem) were added to the cells as a secondary antibody for $2 \mathrm{~h}$ at room temperature. After washing several times, $0.1 \% o$-phenylenediamine in $0.05 \mathrm{M}$ citrate buffer at $\mathrm{pH} 4.5-0.002 \% \mathrm{H}_{2} \mathrm{O}_{2}$ was added for $10 \mathrm{~min}$ at room temperature in the dark. The color reaction was stopped with $1 \mathrm{M} \mathrm{H}_{2} \mathrm{SO}_{4}$ and measured with a photometer at $490 \mathrm{~nm}$ wavelength. In all assays, the absorbance values of the IgG isotypes were subtracted from those of the specific primary antibodies.

\section{RT-PCR ASSAY}

Total RNA was isolated from human cerebral endothelial cells alone $\left(2.5 \times 10^{5}\right)$ and in co-culture with glial cells using a columnbased method (RNeasy mini kit, Qiagen GmbH, Hilden, Germany) according to the manufacturer's instructions. One hundred ng of total RNA, measured using a NanoDrop 10000 spectrophotometer (Thermo Fisher Scientific), were retrotranscripted and $2 \mu \mathrm{l}$ of the cDNA library was used for each PCR. The specific primer pairs used in the PCR are shown in Table 2.

The housekeeping gene $\beta$-actin was amplified simultaneously in order to normalize the mRNA values.

Total RNA with $1 \mu$ l of Oligo dT (Sigma, St. Louis, USA) was denatured at $70^{\circ} \mathrm{C}$ for $10 \mathrm{~min}$, then reverse transcription reagents were added. The RT reaction mixture contained dNTPs mixes (0.5 $\mu \mathrm{M}$ each), $1 \mathrm{U} / \mu 1$ RNase inhibitor (Sigma), $1 \times$ eAMV buffer, $1 \mathrm{U} / \mu \mathrm{l}$ eAMV reverse transcriptase (Sigma) and water, in a final volume of $20 \mu \mathrm{l}$. The RT reaction was performed at $42^{\circ} \mathrm{C}$ for $1 \mathrm{~h}$ and inactivated by incubating the mixture at $75^{\circ} \mathrm{C}$ for $2 \mathrm{~min}$. Two microliters of the cDNA library was subjected to PCR in a Minicycler thermal cycler (MJ Research, Waltham, MA, USA). The PCR reaction mixture contained $0.2 \mathrm{mM}$ dNTPs mix, $0.25 \mu \mathrm{M}$ of each

Table 2 | Primers used in RT-PCR analysis.

\begin{tabular}{|c|c|c|c|}
\hline & Primer forward $\left(5^{\prime} \rightarrow 3^{\prime}\right)$ & Primer reverse $\left(5^{\prime} \rightarrow 3^{\prime}\right)$ & Product size (bp) \\
\hline \multicolumn{4}{|c|}{ TIGHT JUNCTION PROTEINS } \\
\hline OCLN & AAGCAAGTGAAGGGATCTGC & GGGGTTATGGTCCAAAGTCA & 204 \\
\hline CLN-5 & ATGTCGTGCGTGGTGCAGAG & GGTGCAGACCCAGGCGCCGCA & 413 \\
\hline \multicolumn{4}{|c|}{ DRUG TRANSPORTERS } \\
\hline MRP-1 & ATGTCACGTGGAATACCAGC & GAAGACTGAACTCССTTCCT & 349 \\
\hline MRP-2 & ACAGAGGCTGGTGGCAACC & АССАTTACСTTGTCACTGTCCATGA & 227 \\
\hline P-gp & AAGGCCTAATGCCGAACACA & TTTGCCATCAAGCAGCACTTT & 227 \\
\hline \multicolumn{4}{|c|}{ HOUSEKEEPING GENE } \\
\hline$\beta$-actin & TCGTGATGGACTCCGGTGAC & CGCCAGACAGCACTGTGTTG & 452 \\
\hline
\end{tabular}

OCLN, occludin; ZO-1, zonula occludens; CLN-5, claudin-5; oatp1, organic anion-transporting polypeptide-1; oatp3, organic anion-transporting polypeptide-3; MRP-1, multidrug resistance protein-1; MRP-2, multidrug resistance protein-2; P-gp, P-glycoprotein. 
primer, $1 \times$ PCR buffer, $0.05 \mathrm{U} / \mu 1$ Jump Start REDTaq DNA polymerase (Sigma) and water, in a final volume of $50 \mu$ l. For occludin, MRP-1, P-gp, oatp1, and oatp3, amplification started with DNA denaturation at $95^{\circ} \mathrm{C}$ for $2 \mathrm{~min}$, followed by 45 cycles at $95^{\circ} \mathrm{C}$ for $1 \mathrm{~min}, 55^{\circ} \mathrm{C}$ for $30 \mathrm{~s}, 72^{\circ} \mathrm{C}$ for $1 \mathrm{~min}$, and was stopped with a final extension step at $72^{\circ} \mathrm{C}$ for $5 \mathrm{~min}$.

For ZO-1 and MRP-2, amplification started with DNA denaturation at $95^{\circ} \mathrm{C}$ for $2 \mathrm{~min}$, followed by 45 cycles of $95^{\circ} \mathrm{C}$ for $1 \mathrm{~min}, 60^{\circ} \mathrm{C}$ for $30 \mathrm{~s}, 72^{\circ} \mathrm{C}$ for $1 \mathrm{~min}$, and was stopped with a final extension step at $72^{\circ} \mathrm{C}$ for $5 \mathrm{~min}$. The PCR products were subjected to electrophoresis on a $2 \%$ agarose gel stained with ethidium bromide. The relative gel bands were analyzed using a computerized densitometric analysis system (Quantity One 4.4.0, Biorad, Hercules, CA, USA) and the protein $/ \beta$-actin ratio was calculated.

\section{DRUG TRANSPORTER FUNCTIONAL ASSAYS}

The functionality of some transporters (P-gp and MRP-1) was tested by assessing the uptake of the substrate calcein-AM (specific for P-gp and MRP-1) in the absence or presence of specific inhibitors such as verapamil for P-gp and MK-571 for MRP-1, respectively. The assay was performed as previously described (Hollò et al., 1994). Briefly, $2 \times 10^{6}$ brain endothelial cells $/ \mathrm{ml}$ cultured alone or in the presence of glial cells as above described, were washed and then cultured in HPMI medium in 96-well microplates at $37^{\circ} \mathrm{C}$ with $0.25 \mu \mathrm{M}$ calcein-AM (Sigma) added from a stock solution in dimethyl sulfoxide, for $10 \mathrm{~min}$ in the absence or presence of the specific inhibitors ( $40 \mu \mathrm{M}$ verapamil, $10 \mu \mathrm{M} \mathrm{MK}$ 571, respectively, all from Sigma) preincubated for $5 \mathrm{~min}$. Cells were trypsinized for $15 \mathrm{~min}$, washed, then incubated with $1 \%$ Triton X-100 in HPMI for $5 \mathrm{~min}$ and fluorescence was measured in a Perkin Elmer LS 30 fluorescence spectrophotometer with $493 \mathrm{~nm}$ excitation and 515 emission wavelengths. A calibration curve of dye concentration was performed measuring free calcein (Sigma) fluorescence at the identical conditions as calcein-AM.

\section{STATISTICAL ANALYSIS}

Comparison of the cellular ELISA assays as well as immunoblotting and PCR gel band density was performed with the paired $t$-test. Normal distribution of the data was tested by the
Kolmogorov-Smirnov test. $p<0.05$ was considered significant. Statistical analysis was performed with the GraphPad Prism version 3.0 software, San Diego, CA, USA.

\section{RESULTS}

\section{CELL VIABILITY AND TEER ASSESSMENT}

At 7 DIV, an MTT assay revealed a significant (13\%) increase of cell viability in the presence of astroglial cells $(p=0.0077)$. A very significant $(47 \%)$ increase of TEER was also detected at 7 DIV in brain endothelial cells in the presence of astroglial cells $(p<0.0001$; Figures 2A,B).

\section{EXPRESSION OF TIGHT JUNCTION AND DRUG EFFLUX TRANSPORTER PROTEINS}

In the co-culture system with glial cells, TJ proteins (ZO-1, OCLN and CLN-5) showed significantly higher expression compared to the cultures of brain endothelial cells alone, ranging from $13.3 \%$ for OCLN ( $p=0.002)$ to $14.3 \%$ for CLN-5 $(p<0.0001)$ as well as $21 \%$ for ZO-1 ( $p=0.0043$; Figure 3A). A significantly increased expression of several drug transporters (P-gp, MRP-2, oatp1) was also observed in brain endothelial cells co-cultured with glial cells, ranging from $9.4 \%$ for MRP-2 to $19 \%$ for P-gp ( $p=0.009$ and $p=0.0013$, respectively); oatp1 was found to be increased by $12.5 \%(p=0.0005)$. In contrast, no significant change was observed for MRP-1 $(+2.8 \%, p=0.33)$ and oatp3 $(+9 \%, p=0.23$, respectively; Figure 3B).

\section{EXPRESSION OF TIGHT JUNCTION AND DRUG EFFLUX TRANSPORTER MRNA LEVELS}

When brain endothelial cells were co-cultured with glial cells, a significant increase of gene transcripts was found for all TJ proteins with different extent. In particular, transcripts of ZO-1 a and b increased by 90 and $101 \%, p=0.0017$ and 0.0099 , respectively. A higher increase was found for OCLN and CLN-5 (124 and 168\%, $p=0.0003$ and 0.0005 , respectively). A wide range of increase was found for the transcripts of drug transporter proteins. Oatp3 increased by $40 \%(p=0.014)$ and P-gp by $48 \%(p=0.0073)$. By contrast, oatp 1 increased by $218 \%(p=0.0097)$, MRP- 1 by $328 \%$ $(p=0.006)$ and MRP-2 by $149 \%(p=0.025$; Figure 4$)$.
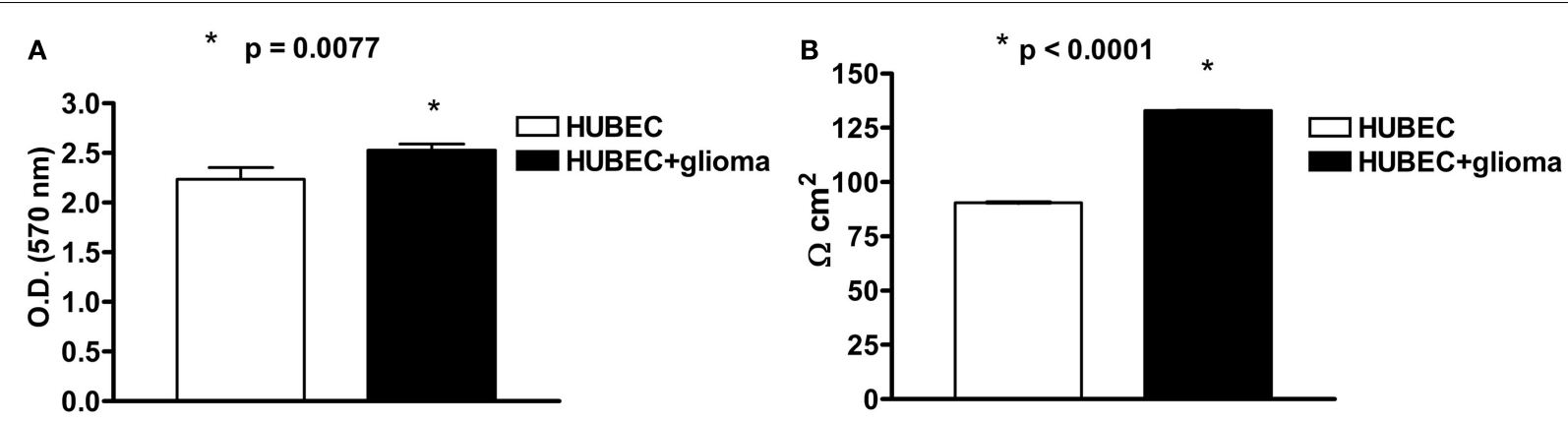

FIGURE 2 | (A) Cell viability of human brain endothelial cells (HUBEC) in the presence or absence of glioma cells. The results are shown as mean \pm SEM of optical density (OD) values of duplicate batches of three independent cultures $\left(2 \times 10^{4}\right.$ cells/well) from three different tumors listed in Table $\mathbf{1}(n=3)$. (B) Transendothelial electrical resistance of human brain endothelial cells (HUBEC) in the presence or absence of glioma cells. The results are expressed as mean \pm SEM of $\Omega \mathrm{cm}^{2}$ of duplicate batches of three independent cultures $\left(2 \times 10^{4}\right.$ cells/well) from three different tumors listed in Table $1(n=3)$. 


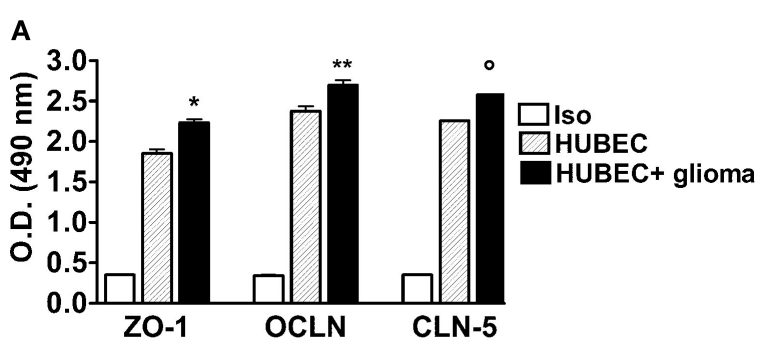

FIGURE 3 | (A) Expression of tight junction proteins in human brain endothelial cell cultures (HUBEC) in the presence or absence of glioma cells. The results are shown as mean \pm SEM of optical density (OD) values of duplicate batches of three independent cultures from three different tumors listed in Table 1 ( $n=3$ ). Iso, antibody isotype; ZO-1, zonula occludens; OCLN, occludin; CLN-5, claudin-5. $*$ HUBEC vs HUBEC + glioma, $p=0.0005$; $* *$ HUBEC vs HUBEC + glioma, $p=0.002 ;{ }^{\circ} \mathrm{HUBEC}$ vs HUBEC + glioma, $p<0.0001$ (paired t-test). (B) Expression of drug transporter proteins in human brain endothelial cell cultures (HUBEC) in

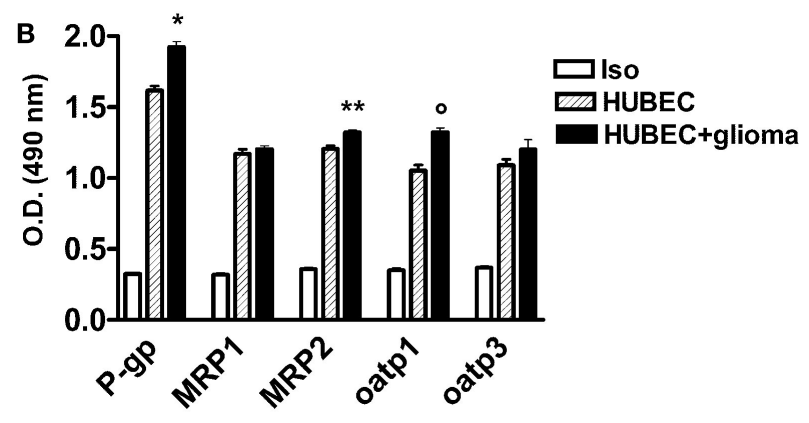

the presence or absence of glioma cells. The results are shown as mean \pm SEM of optical density (OD) values of duplicate batches of three independent cultures from three different tumors listed in Table $1(n=3)$. Iso, antibody isotype; P-gp, P-glycoprotein; MRP-1, multidrug resistance protein-1; MRP-2, multidrug resistance protein-2; oatp1, organic anion-transporting polypeptide-1; oatp3, organic anion-transporting polypeptide-3. $*$ HUBEC vs HUBEC + glioma, $p=0.001 ; * *$ HUBEC vs HUBEC + glioma, $p=0.009$; ${ }^{\circ} \mathrm{HUBEC}$ vs HUBEC + glioma, $p=0.0005$ (paired $t$-test).

\section{DRUG TRANSPORTER FUNCTIONAL ASSAYS}

To test whether expressed P-gp and MRP-1 were functionally active, we assessed the rate of calcein-AM uptake by endothelial cells. We found that brain endothelial cells cultured alone, were able to uptake very low amounts of calcein-AM that markedly increased, in the presence of the specific inhibitors verapamil and MK-571, by 178 and 167\%, respectively. When brain endothelial cells were co-cultured with glial cells, a significantly higher increase of uptake of calcein-AM than that of brain endothelial cells cultured alone was found (with no inhibitors by $47 \%, p=0.025$; in the presence of verapamil by $681 \%, p=0.01$; in the presence of MK-571 by $553 \%, p=0.0075)$ indicating a significantly higher availability of functionally active P-gp and MRP-1 (Figure 5).

\section{DISCUSSION}

Our study demonstrates that an in vitro model of the human BBB may be obtained from cryopreserved brain tumor specimens belonging to the glial cell phenotype. In particular, brain endothelial cells isolated from these tissues displayed high viability and retained several physiological properties including the ability to form TJs, as shown by the constitutive expression of the principal proteins participating in their formation, such as OCLN, ZO-1, and CLN-5, at both protein and gene transcript level. In addition, P-gp and MRP-1 were found to be functionally active. These findings suggest that isolated vessels from glial tumors, although displaying in situ genomic alterations similar to those found in glioma cells (reviewed in Hjelmeland et al., 2011), are able to express in vitro, at the culture conditions used in our model, the physiological properties needed to establish valid monolayers to build a BBB model. We found high viability in brain endothelial cells obtained from brain tumor tissues that were cryopreserved for up to 3 months (data not shown). We also found a low variability of the main parameters tested such as TEER, TJ protein expression and functional activity of two important drug transporters such as P-gp and MRP-1 among specimens from different glial tumors such as astrocytomas of low and high grade of malignancy and glioblastoma multiform. This finding demonstrates that different glial tumors, independently of their degree of malignancy, may be used and eventually pooled to obtain reproducible primary brain endothelial cultures. TJs are the result of complex interactions between several transmembrane and cytoskeletal proteins. ZO-1 is fundamental in linking other TJ proteins, such as CLNs, OCLN and JAM-1, to the actin cytoskeleton (Farshori and Kachar, 1999; Mitic et al., 2000). In our model, in vitro TJ formation was also documented by the detection of reliable TEER values, suggesting the development of a valid electrical resistance due to cell monolayer tightness. Furthermore, brain endothelial cells expressed a number of transporter proteins that are involved in maintaining brain homeostasis by selectively regulating the passage of compounds across the $\mathrm{BBB}$ and inhibiting the delivery of drugs into the brain parenchyma. It is therefore important to obtain in vitro $\mathrm{BBB}$ models that are capable of providing adequate experimental conditions to study the influence of transporters in pharmacological resistance and to test the ability to enter brain parenchyma of new drugs targeting the CNS. In the primary brain endothelial cells co-cultured with glial cells we found a significant increase in the expression of TJ proteins, as well as transporter proteins and up-regulation of their related transcripts, confirming previous observations in other brain endothelial cell cultures (Cecchelli et al., 1999). This increase differed among the individual proteins. In particular oatp3, an organic anion transporter located mainly at the apical and basolateral side of brain capillary endothelial cells and at the apical side of choroid plexus (Kusahara et al., 2003) and MRP-1 were found to be slightly changed at the protein expression level but displayed a significant up-regulation of their related gene transcripts, suggesting a different post-transcriptional pathway of regulation that remains to be elucidated. With regard to ZO-1, we found a significant up-regulation of both gene transcripts, detected as result of alternative RNA splicing (Willott et al., 1992). This finding suggests that both isoforms, expressed in human brain endothelial cells, are subjected to regulation by a putative gliaderived factor. A significantly high increase was also found at the 
A

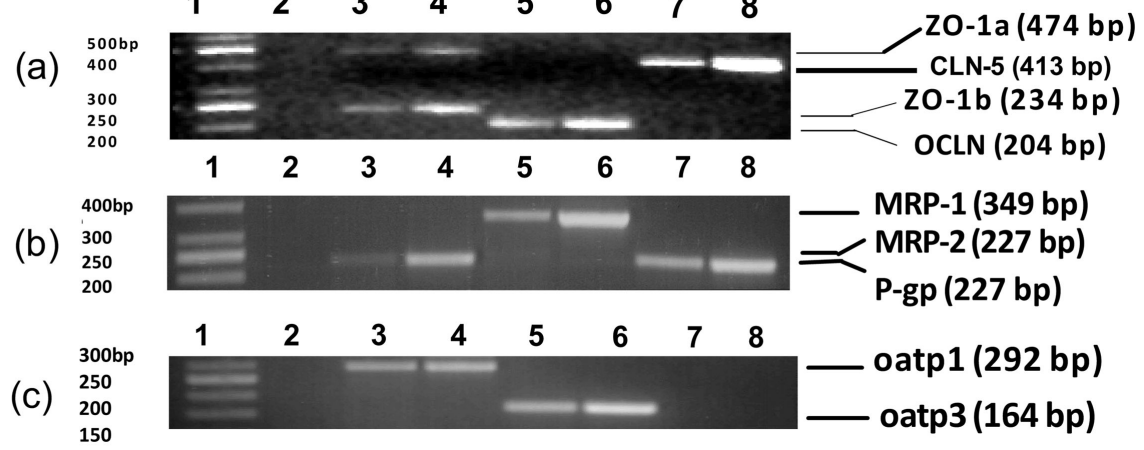

(d) $\begin{aligned} & 600 \mathrm{bp} \\ & 500 \\ & 400\end{aligned}-\square-\cdots-\operatorname{actin}(452 \mathrm{bp})$

B

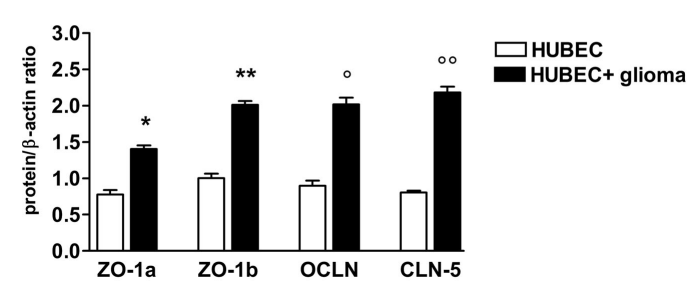

C

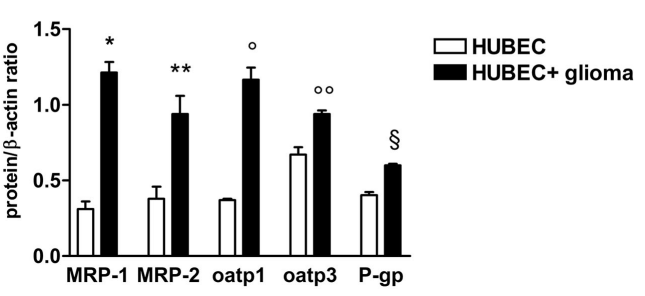

FIGURE 4 | RT-PCR analysis of tight junction and drug transporter gene transcripts in human brain endothelial cell cultures (HUBEC) in the presence or absence of glioma cells. (A) Representative ethidium bromide-stained agarose gels of the RT-PCR amplified tight junction and drug transporter gene mRNA and $\beta$-actin gene. (a) Lane 1: DNA ladder markers; lane 2: negative control obtained omitting reverse transcriptase from the RT mixture; lane 3: ZO-1a and ZO-1b in the absence of glioma cells; lane 4: ZO-1a and ZO-1b in the presence of glioma cells; lane 5: OCLN in the absence of glioma cells; lane 6: OCLN in the presence of glioma cells; lane 7: CLN-5 in the absence of glioma cells; lane 8: CLN-5 in the presence of glioma cells. (b) Lane 1: DNA ladder markers; lane 2: negative control; lane 3: MRP-2 in the absence of glioma cells; lane 4: MRP-2 in the presence of glioma cells; lane 5: MRP-1 in the absence of glioma cells; lane 6: MRP-1 in the presence of glioma cells; lane 7: P-gp in the absence of glioma cells; lane 8: P-gp in the presence of glioma cells. (c) Lane 1: DNA ladder markers; lane 2: negative control; lane 3: oatp1 in the absence of glioma cells; lane 4: oatp1 in the presence of glioma cells; lane 5: oatp3 in the absence of glioma cells; lane 6: oatp3 in the presence of glioma cells; lane 7-8: negative control. (d) Lane 1: DNA ladder markers; lane 2: negative control; lane 3-8: $\beta$-actin gene. On the left, base pair (bp) size of the DNA ladder markers, on the right, bp size of the gene products. (B) Expression ratios of tight junction mRNA obtained dividing tight junction mRNA densitometric values by those of $\beta$-actin. The results are expressed as mean \pm SEM of three independent cultures in the presence or absence of glioma cells from three different tumors listed in Table $\mathbf{1}(n=3)$. *HUBEC vs HUBEC + glioma, $p=0.0017 ; * *$ HUBEC vs HUBEC + glioma, $p=0.009 ;{ }^{\circ} \mathrm{HUBEC}$ vs HUBEC + glioma, $\mathrm{p}=0.0003 ;{ }^{\circ} \mathrm{HUBEC}$ vs HUBEC + glioma, $p=0.0005$ (paired $t$-test). (C) Expression ratios of drug transporter mRNA obtained dividing drug transporter mRNA densitometric values by those of $\beta$-actin. The results are expressed as mean \pm SEM of three independent cultures in the presence or absence of glioma cells from three different tumors listed in Table $1(n=3)$. *HUBEC vs HUBEC + glioma, $p=0.006 ; * * H U B E C$ vs HUBEC + glioma, $p=0.025$; ${ }^{\circ} \mathrm{HUBEC}$ vs HUBEC + glioma, $p=0.0097 ;{ }^{\circ}$ HUBEC vs HUBEC + glioma, $p=0.014$; ${ }^{\S} \mathrm{HUBEC}$ vs HUBEC + glioma, $p=0.0073$ (paired $t$-test). ZO-1, zonula occludens; OCLN, occludin; CLN-5, claudin-5; P-gp, P-glycoprotein; MRP-1, multidrug resistance protein-1; MRP-2, multidrug resistance protein-2; oatp1, organic anion-transporting polypeptide-1; oatp3, organic anion-transporting polypeptide-3. both protein and gene transcript level for CLN-5, a member of the claudin family mainly detected in brain endothelial cells at the TJs (Morita et al., 1999) and found to be decreased in a murine cerebral endothelial line exposed to sera of patients with multiple sclerosis on clinical relapse (Blecharz et al., 2010).

The role of glia in the differentiation and induction of functional properties in the brain endothelium is well known and probably depends on cell-cell contact, as well as on soluble factors secreted by glial cells, some of which have been identified or are thought to play a role in this activity such as cyclic AMP (Beuckmann et al., 1995). However, the nature of other possible soluble factors is unknown and remains to be elucidated. Our model differs from other co-culture systems due to the presence of glial cells derived from the same brain tissue specimen that the brain endothelial cells were isolated from, growing in the same feeding medium as that of the brain endothelial cells, although not in close contact (as in other culture systems in which glial cell lines were grown on the opposite side of filter membranes containing immortalized human brain endothelial cell lines; Megard et al., 2002). The central role of astrocytes in inducing physiological properties in human brain endothelial cells to establish BBB monolayers was further highlighted in an in vitro $\mathrm{BBB}$ model by co-culturing commercially available human brain endothelial cells with human astrocytes making cell-cell contact via a porous synthetic membrane (Kuo and Lu, 2011). The findings of our model are consistent with those of another recent study demonstrating that human brain endothelial cells derived from a cell line and co-cultured, with no cell-cell contact, with human fetal astrocytes 


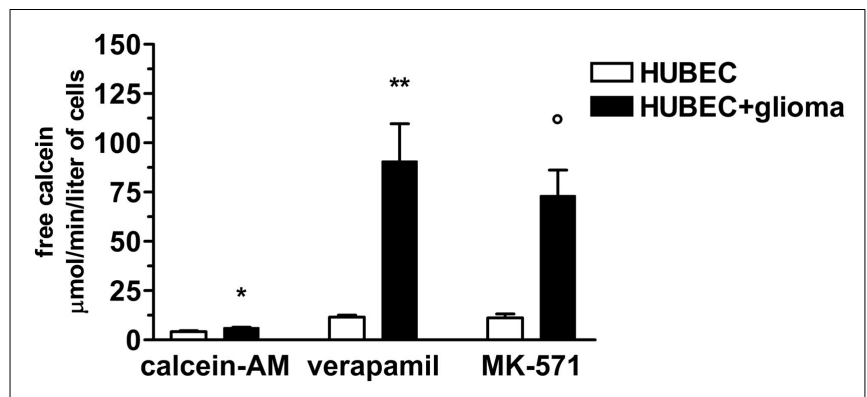

FIGURE 5 | Calcein uptake by brain endothelial cultures in the presence or absence of P-gp and MRP-1 inhibitors (verapamil and MK-571, respectively). The results are expressed as mean \pm SEM of duplicate batches of three independent cultures in the presence or absence of glioma cells from three different tumors listed in Table $\mathbf{1}(n=3)$. Calcein-AM, brain endothelial cultures exposed to calcein-AM; Verapamil, brain endothelial cultures preincubated with verapamil; MK-571, brain endothelial cultures preincubated with MK-571; HUBEC, human brain endothelial cells; HUBEC + glioma, human brain endothelial cells in the presence of glioma cells. $*$ HUBEC vs HUBEC + glioma, $p=0.025$; $* * H U B E C$ vs HUBEC + glioma, $p=0.01 ;{ }^{\circ} \mathrm{HUBEC}$ vs HUBEC + glioma, $p=0.0075$ (paired $t$-test).

showed increased TEER values and higher expression of ZO-1 (Siddharthan et al., 2007). The lack of cell-cell contact, though different from the real BBB structure, may however allow to study and attempt to isolate eventual soluble glia-derived growth factors acting on the brain endothelial cells by comparing the findings obtained in brain endothelial cultures alone and in the presence of glial cells. It also provides a tool for the study of native brain endothelium surface molecules involved in cell trafficking and the passage of compounds across the $\mathrm{BBB}$, thus overcoming the species differences present in other culture systems using non-human nervous tissues.

\section{REFERENCES}

Abbott, N. J. (2000). Inflammatory mediators and modulation of blood-brain barrier permeability. Cell. Mol. Neurobiol. 20, 131-147.

Annunziata, P. (2003). Blood-brain barrier changes during invasion of the central nervous system by HIV1. Old and new insights into the mechanism. J. Neurol. 250, 901-906.

Annunziata, P., Cioni, C., Moschini, F., Riccucci, A., and Guazzi, G. C. (1995). Serum anti-brain endothelium antibodies and cognitive assessment in patients with Binswanger's encephalopathy. J. Neurol. Sci. 128, 96-102.

Annunziata, P., Cioni, C., Toneatto, S., and Paccagnini, E. (1998). HIV-1 gp 120 increases the permeability of rat brain endothelium cultures by a mechanism involving substance P. AIDS 12, 2377-2385.
Arthur, F. E., Shivers, R. R., and Bowmann, P. D. (1987). Astrocytemediated induction of tight junctions in brain capillary endothelium: an efficient in vitro model. Brain Res. 433, 155-159.

Ballabh, P., Braun, A., and Nedergaard, M. (2004). The blood-brain barrier: an overview: structure, regulation, and clinical implications. Neurobiol. Dis.16, 1-13.

Bell, R. D., and Zlokovic, B. V. (2009). Neurovascular mechanisms and blood-brain barrier disorder in Alzheimer's disease. Acta Neuropathol. 118, 103-113.

Beuckmann, C., Hellwig, S., and Galla, H. J. (1995). Induction of the blood/brain- barrier-associated enzyme alkaline phosphatase in endothelial cells from cerebral capillaries is mediated via cAMP. Eur. J. Biochem. 229, 641-644.

Biegel, D., Spencer, D. D., and Pachter, J. S. (1995). Isolation and culture

Recently, two human BBB models have been described, one based on commercially available human brain endothelial cells cocultured with astroglial cells derived from adult normal human cerebral tissue (Megard et al., 2002). This model was found suitable to test passage of indinavir, a known anti-HIV-1 protease inhibitor. The other one was an incomplete model based on use of an immortalized human brain endothelial cell line with lentivirus infection but without astroglial cell contact (Weksler et al., 2005). Our model represents an additional complete BBB model displaying all characteristics suitable to study eventual changes of TJ proteins as well drug transporters exposed to biological fluids or supernatants of immunocompetent cells derived from patients with several neurological disorders. The main advantage of our proposed model is the cryopreservation of the nervous tissue used for preparing primary endothelial cell cultures. This allows to obtain sufficient amount of specimens that could be pooled later and provide a large number of primary brain endothelial cells circumventing the known obstacle to expand in vitro endothelial cells derived from human adult brain tissue.

Alterations in BBB functionality and permeability have been shown in several immune-mediated or infectious and degenerative neurological diseases, such as multiple sclerosis (Minagar and Alexander, 2003), HIV-related neurological disorders (reviewed in Annunziata, 2003) and Alzheimer's disease (Bell and Zlokovic, 2009). Our primary brain endothelium culture system, which mimics a physiologically relevant situation, may therefore provide a new tool for studying the effects of biological fluids such as serum and cerebrospinal fluid from patients with neurological disorders underlying a BBB alteration in disease pathogenesis.

\section{ACKNOWLEDGMENTS}

This work was supported by a research grant from Siena Biotech S.p.A. to Pasquale Annunziata.

of human brain microvessel endothelial cells for the study of blood-brain barrier properties in vitro. Brain Res. 692, 183-189.

Blecharz, K. G., Haghikia, A., Stasiolek, M., Kruse, N., Drenckhahn, D., Gold, R., Roewer, N., Chan, A., and Förster, C. Y. (2010). Glucocorticoid effects on endothelial barrier function in the murine brain endothelial cell line cEND incubated with sera from patients with multiple sclerosis. Mult. Scler. 16, 293-302.

Bradbury, M. W. (1985). The bloodbrain barrier. Transport across the cerebral endothelium. Circ. Res. 57, 213-222.

Bradbury, M. W. (1993). The bloodbrain barrier. Exp. Physiol. 78, 453-472.

Brunet, J. F., Pellerin, L., Magistretti, P., and Villemure, J. G. (2003). Cryopreservation of human brain tissue allowing timely production of viable adult human brain cells for autologous transplantation. Cryobiology 47, 179-183.

Cecchelli, R., Dehouck, B., Descamps, L., Fenart, L., Bluée-Scherrer, V. V., Duhem, C., Lundquist, S., Rentfel, M., Torpier, G., and Dehouck, M. P. (1999). In vitro model for evaluating drug transport across the bloodbrain barrier. Adv. Drug Deliv. Rev. 36, 165-178.

Cioni, C., Cantalupo, L., Turlizzi, E., Zanelli, U., and Annunziata, P. (2009). Expression of tight junction and drug efflux transporter proteins in a model of human bloodbrain barrier. J. Neurol. 256(Suppl. 2), S190-S191.

Cordon-Cardo, C., O’Brien, J. P., Casals, D., Rittman-Grauer, L., Biedler, J. L., Melamed, M. R., and Bertino, J. R. (1989). Multidrug-resistance gene (P-glycoprotein) is expressed by endothelial cells at blood-brain barrier sites. Proc. Natl. Acad. Sci. U.S.A. 86, 695-698. 
Culot, M., Lundquist, S., Vanuxeem, D., Nion, S., Landry, C., Delplace, Y., Dehouck, M. P., Berezowski, V., Fenart, L., and Cecchielli, R. (2008). An in vitro blood-brain barrier model for high throughput (HTS) toxicological screening. Toxicol. In vitro 22, 799-811.

De Lange, E. C. M. (2004). Potential role of $\mathrm{ABC}$ transporters as a detoxification system at the blood-CSF barrier. Adv. Drug Deliv. Rev. 56, 1793-1809.

Dehouk, M. P., Meresse, S., Delorme, P., Fruchart, J. C., and Cecchelli, R. (1990). An easier, reproducible and mass-production method to study the blood-brain barrier in vitro. $J$. Neurochem. 54, 1798-1801.

Farshori, P., and Kachar, B. (1999). Redistribution and phosphorylation of occludin during opening and resealing of tight junctions in cultured epithelial cells. J. Membr. Biol. 170, 147-156.

Gao, B., Stieger, B., Noé, B., Fritschy, J. M., and Meier, P. J. (1999). Localization of the organic anion transporting polypeptide 2 (oatp2) in capillary endothelium and choroid plexus epithelium of rat brain. J. Histochem. Cytochem. 47, 1255-1264.

Goldstein, G. W., and Betz, A. L. (1986). The blood-brain barrier. Sci. Am. 255, 74-83.

Hjelmeland, A. B., Lathia, J. D., Sathornsumetee, S., and Rich, J. N. (2011). Twisted tango: brain tumor neurovascular interactions. Nat. Neurosci. 14, 1375-1381.

Hollò, Z., Homolya, L., Davis, C. W., and Sarkadi, B. (1994). Calcein accumulation as a fluorometric functional assay of the multidrug transporter. Biochim. Biophys. Acta 1191, 384-388.

Janzer, R. C., and Raff, M. C. (1987). Astrocytes induce blood-brain barrier properties in endothelial cells. Nature 325, 253-257.

Kalback, W., Esh, C., Castaño, E. M., Rahman, A., Kokjohn, T., Luehrs, D. C., Sue, L., Cisneros, R., Gerber,
F., Richardson, C., Bohrmann, B., Walker, D. G., Beach, T. G., and Roher, A. E. (2004). Atherosclerosis, vascular amyloidosis and brain hypoperfusion in the pathogenesis of sporadic Alzheimer's disease. Neurol. Res. 26, 525-539.

Kermode, A. G., Thompson, A. J., Tofts, P., MacManus, D. G., Kendall, B. E., Kingsley, D. P., Mosely, I. F., Rudge, P., and McDonald, W. I. (1990). Breakdown of the blood-brain barrier precedes symptoms and other MRI signs of new lesions in multiple sclerosis. Pathogenetic and clinical implications. Brain 113, 1477-1489.

Kuo, Y. C., and Lu, C. H. (2011). Effect of human astrocytes on the characteristics of human brain- microvascular endothelial cells in the blood-brain barrier. Colloids Surf. B Biointerfaces 86, 225-231.

Kusahara, H., He, Z., Nagata, Y., Nozaki, Y., Ito, T., Masuda, H., Meyer, P. J., Abe, T., and Sugiyama, Y. (2003). Expression and functional involvement of organic anion transporting polypeptide subtype 3 (Slc21a7) in rat choroids plexus. Pharm. Res. 20, 720-727.

Megard, I., Garrigues, A., Orlowski, S., Jorajuria, S., Clayette, P., Ezan, E., and Mabondzo, A. (2002). A co-culture-based model of human blood-brain barrier: application to active transport of indinavir and in vivo-in vitro correlation. Brain Res. 927, 153-167.

Meyer, J., Mischeck, U., Veyhl, M., Henzel, K., and Galla, H. J. (1990). Bloodbrain barrier characteristic enzymatic properties in cultured brain capillary endothelial cells. Brain Res. 514, 305-309.

Meyer, J., Rauh, J., and Galla, H. J. (1991). The susceptibility of cerebral endothelial cells to astroglial induction of blood-brain barrier enzymes depends on their proliferative state. J. Neurochem. 57, 1971-1977.

Minagar, A., and Alexander, J. S. (2003). Blood-brain barrier disruption in multiple sclerosis. Mult. Scler. 9, 540-549.

Mitic, L. L., Van Itallie, C. M., and Anderson, J. M. (2000). Molecular physiology and pathophysiology of tight junctions I. Tight junction structure and function: lessons from mutant animals and proteins. Am. J. Physiol. Gastrointest. Liver Physiol. 279, 250-254

Morita, K., Sasaki, H., Furuse, M. and Tsukita, S. (1999). Endothelial claudin: claudin-5/TMVCF constitutes tight junction strands in endothelial cells. J. Cell Biol. 147, 185-194.

Mrsulja, B. B., Mrsulja, B. J, Fujimoto, T., Klatzo, I., and Spatz, M. (1976). Isolation of brain capillaries: a simplified technique. Brain Res. 110, 361-365.

Perrière, N., Yousif, S., Cazaubon, S., Chaverot, N., Bourasset, F., Cisternino, S., Declèves, X., Hori, S., Terasaki, T., Deli, M., Scherrmann, J. M., Temsamani, J., Roux, F., and Couraud, P. O. (2007). A functional in vitro model of rat blood-brain barrier for molecular analysis of efflux transporters. Brain Res. 1150, 1-13.

Rubin, L. L., Hall, D. F., Porter, S., Barbu, K., Cannon, C., Horner, H. C., Janatpour, M., Liaw, C. W., Manning, K. Morales, J., Tanner, L. I., Tomaselli, K. J., and Bard, F. (1991). A cell culture model for the blood-brain barrier. J. Cell Biol. 115, 1725-1735.

Siddharthan, V., Kim, Y. V., Liu, S. and Kim, K. S. (2007). Human astrocytes/astrocyte-conditioned medium and shear stress enhance the barrier properties of human brain microvascular endothelial cells. Brain Res. 1147, 39-50.

Smith, T. W., De Girolami, U., Hénin, D., Bolgert, F., and Hauw, J. J. (1990). Human immunodeficiency virus (HIV) leukencephalopathy and the microcirculation. J. Neuropathol. Exp. Neurol. 49, 357-370.
Teifel, M., and Friedl, P. (1996). Establishement of the permanent microvascular endothelial cell line PBMEC/C1-2 from porcine brains. Exp. Cell Res. 228, 50-57.

Weksler, B. B., Subileau, A., Perrière, N., Charneau, P., Holloway, K., Leveque, M., Tricoire-Leignel, H., Nicotra, A., Bourdoulous, S., Turowski, P. Male, D. K., Roux, F., Greenwood, J., Romero, I. A., and Couraud, P. O. (2005). Blood-brain barrier-specific properties of a human adult brain endothelial cell line. FASEB J. 19, 1872-1874.

Willott, E., Balda, M. S., Heintzelman, M., Jameson, B., and Anderson, J. M. (1992). Localization and differential expression of two isoforms of tight junction protein ZO-1. Am. J. Physiol. 262, C1119-C1124.

Conflict of Interest Statement: The authors declare that the research was conducted in the absence of any commercial or financial relationships that could be construed as a potential conflict of interest.

Received: 18 November 2011; paper pending published: 15 December 2011; accepted: 24 April 2012; published online: 11 May 2012.

Citation: Cioni C, Turlizzi E, Zanelli $U$, Oliveri $G$ and Annunziata $P$ (2012) Expression of tight junction and drug efflux transporter proteins in an in vitro model of human blood-brain barrier. Front. Psychiatry 3:47. doi: 10.3389/fpsyt.2012.00047

This article was submitted to Frontiers in Neurodegeneration, a specialty of Frontiers in Psychiatry.

Copyright (C) 2012 Cioni, Turlizzi, Zanelli, Oliveri and Annunziata. This is an open-access article distributed under the terms of the Creative Commons Attribution Non Commercial License, which permits non-commercial use, distribution, and reproduction in other forums, provided the original authors and source are credited. 